\title{
Public-private partnership as a necessity for sustainable investment development of the region
}

\author{
Vladislav Y. Sutyagin \\ Department of Finance and Banking \\ Tambov State University named after G. R. Derzhavin \\ Tambov, Russia \\ E-mail: sutyagin.vladislav@yandex.ru
}

\author{
Yana Y. Radyukova \\ Department of Finance and Banking \\ Tambov State University named after G. R. Derzhavin \\ Tambov, Russia \\ E-mail: radyukova68@mail.ru
}

\author{
Elena A. Kolesnichenko \\ Department of Personnel Management \\ Tambov State University named after G. R. Derzhavin \\ Tambov, Russia \\ E-mail: dissovet@tsu.tmb.ru
}

\begin{abstract}
The sanctions policy of the US and EU countries has escalated the traditional problems of the Russian economy. The main problem of ensuring economic growth is low investment activity, which in recent decades has been solved through the inflow of foreign investment. However, the volume of foreign investment since 2014 has fallen sharply.

This problem is relevant not only at the level of the national economy, but also at the level of the economies of Russian regions. The current economic situation is characterized by a deficit of foreign investment and tight monetary policy.

The article substantiates the thesis that in such conditions, for the regional authorities, one of the main tools for supporting investment activity is the development of the institution of public-private partnership. The experience of Tambov region shows that its success in ensuring a high rate of investment in fixed assets (especially in comparison with the other regions of the Central Federal District) is associated with a high dynamics of public-private partnership development. In addition, the article outlines the main problems of development of public-private partnership at the regional level and determines the reserves for its further development.
\end{abstract}

Key words: investments, sustainability of the region, public-private partnership

\section{Introduction}

In recent years, the sustainability of the development of Russian regions is an extremely topical issue. The confrontation with the West revealed many of the systemic problems of the Russian economy. The driving force of the development of any economy is investment. Since the beginning of the $90 \mathrm{~s}$, traditionally, foreign investment has always been of great importance. Unfortunately, we should admit that the expectations did not come up with the final results. It is obvious that in the context of sanctions confrontation between Russia and the EU and US, there might not be any significant progress in the investment area. Moreover, a great part of sanctions measures concerns the investment sphere. In particular, the largest Russian banks (Sberbank, Bank of Moscow, Gazprombank, Rosselkhozbank, Vneshekonombank and VTB) are prohibited from raising capital for long periods. Within the framework of the EU and US sanctions policy these terms have been consistently reduced: initially it was about 90 days, which were then reduced to 30 days and in 2017, the United States shortened the time limits for its financial organizations to 14 days. (1) Similar restrictions apply to the largest companies in the oil and gas sector and the defense industry, for which foreign companies are prohibited from purchasing securities valid for more than 30 days, the supply of products is banned, the import of "dual-use goods and technologies" is prohibited in Russia, innovative technologies for the oil industry are not provided. In early 2018, new US sanctions are expected, which will consistently tighten pressure on the investment sector. In this regard, the problem of investment support for 
economic growth is becoming more acute and relevant not only at the macro level, but at the level of regions.

The topic of public-private partnership in the economic scientific community has been actively touched upon only in recent years, because in the 1900s and 2000s the issues of supporting regional projects were dealt with by means of public funding and interbudgetary transfers. The problem is actively discussed by V.G. Varnavsky, A.V. Klimenko, V.A. Korolev, A.V. Bazhenov, A.M. Vorotnikov, I.I. Savchenko, N.G. Sidorova, E.V. Kocheva, N.A. Matev, D.I. Kuzmin and others. The research is focused on the forms of public-private partnership, the structure and dynamics of projects. At the same time, we should note that at present the ways of motivating the participants in public-private partnership, as well as building regional institutions responsible for implementing the partnership, are rather poorly developed and require further research.

The purpose of this study is to substantiate the importance of public-private partnership in the context of the region investment development.

\section{Methods and Materials}

In the theoretical basis of the study we referred to different methods: a logical method, as well as the methods of analysis and induction. In addition to general scientific methods, statistical methods are also used in our research, including the method of grouping (grouping the regions of the Central Federal District in terms of the growth rate of investment in fixed assets), the method of analyzing the dynamics (analyzing the dynamics of investment in fixed assets in the RF and in the regions of the Central Federal District, private partnership of Tambov region, as well as analyzing the dynamics of the key interest rate of the Bank of Russia and the monetization ratio); the method of structural analysis (analyzing the section structure of investment in fixed assets in Russia in 2012-2015); the method of selective observation (taking into account the rating of public-private partnerships). In addition, analyzing the level of monetization, we used the methods of relative coefficients and comparative analysis (comparing the level of monetization of the Russian economy and other leading economies of the world).

\section{Results and Discussion}

The deficit of external inflow of investment resources is visually characterized by figures, particularly by such a statistical indicator as "investment in fixed assets" over the past few years (Fig. 1).

The problem is not of an abstract nature, it is quite serious in all the regions (for example, the regions of the Central Federal District) (Table 1). Certainly, some regions look somewhat better than the others (for example, Tambov region, Kursk region and Tver region), but in general this does not really matter.

In a situation when there are not enough external investments, there is only hope for internal sources. In November of 2016 the Chairman of the Bank of Russia I.S. Nabiullina openly mentioned that. (4) However, the reality is quite different: the Bank of Russia has permanently conducted a strict monetary policy since the early 1990s. It is well known that the money supply (including the level of bank rates) is determined by the central bank and its accounting policy (Figure 2).

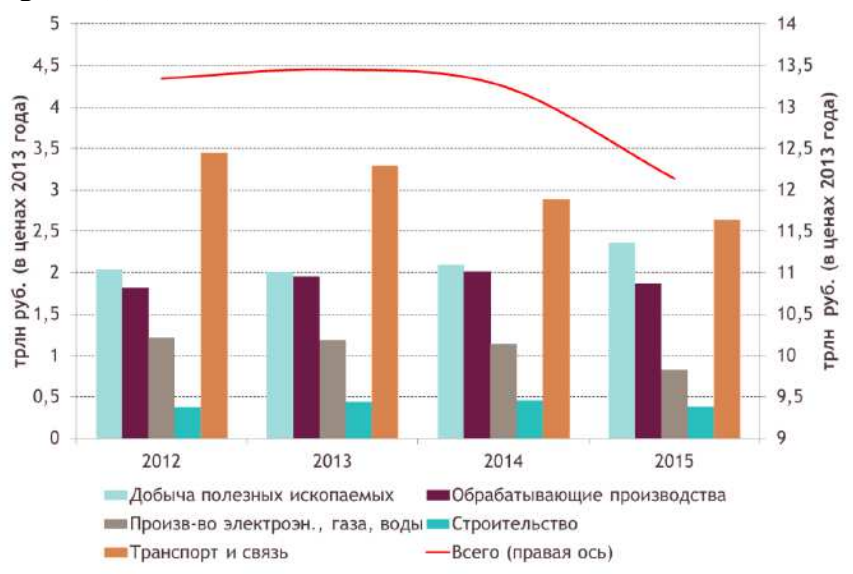

Fig. 1. Dynamics of the volume of investments in fixed assets (for a full range of organizations) by types of activity (taking into account the prices of 2013 (trillion rubles), years 2012-2015. (2) 
TABLE 1. Dynamics of investments in fixed assets (comparing the situation in the subjects of the Russian Federation (CFD) (in comparable prices) 2013-2017. (3)

\begin{tabular}{|c|c|c|c|c|c|c|c|}
\hline & 2010 & 2011 & 2012 & 2013 & 2014 & 2015 & 2016 \\
\hline Russian Federation & 106,3 & 110,8 & 106,8 & 100,8 & $98,5^{1)}$ & 89,9 & 99,8 \\
\hline Belgorod region & 122,3 & 118,4 & 101,4 & 89,7 & 90,7 & 114,3 & 91,3 \\
\hline Bryansk region & 149,5 & 101,0 & 98,0 & 122,0 & 101,7 & 87,2 & 102,8 \\
\hline Vladimir region & 92,6 & 111,5 & 93,5 & 98,2 & 110,4 & 88,9 & 90,2 \\
\hline Voronezh region & 125,3 & 112,3 & 112,6 & 113,7 & 106,7 & 100,7 & 100,1 \\
\hline Ivanovo region & 86,5 & 96,0 & 85,0 & 110,3 & 92,1 & 68,0 & 88,5 \\
\hline Kaluga region & 116,4 & 95,8 & 117,3 & 98,0 & 99,6 & 80,7 & 86,3 \\
\hline Kostroma region & 124,9 & 109,4 & 113,8 & 100,2 & 119,9 & 86,7 & 91,4 \\
\hline Kursk Region & 111,9 & 114,1 & 107,0 & 101,0 & 99,4 & 92,2 & 118,3 \\
\hline Lipetsk region & 116,5 & 102,8 & 78,0 & 103,5 & 100,7 & 100,4 & 103,5 \\
\hline Moscow region & 98,9 & 104,5 & 107,0 & 105,9 & 104,1 & 89,3 & 95,1 \\
\hline Oryol Region & 101,9 & 140,5 & 110,1 & 101,2 & 104,9 & 90,4 & 85,8 \\
\hline Ryazan region & 100,7 & 122,8 & 121,8 & 108,6 & 77,7 & 79,5 & 86,8 \\
\hline Smolensk region & 129,0 & 100,1 & 86,9 & 95,0 & 100,5 & 90,2 & 98,1 \\
\hline Tambov region & 109,9 & 119,1 & 116,7 & 113,6 & 108,0 & 96,1 & 84,0 \\
\hline Tver region & 112,5 & 105,6 & 81,1 & 94,0 & 102,0 & 81,2 & 118,2 \\
\hline Tula region & 112,8 & 103,3 & 100,7 & 100,7 & 100,4 & 100,1 & 100,2 \\
\hline Yaroslavl region & 119,4 & 104,2 & 92,4 & 100,8 & 97,4 & 76,7 & 106,3 \\
\hline Moscow & 95,8 & 106,6 & 133,1 & 107,1 & 104,4 & 97,4 & 101,2 \\
\hline
\end{tabular}

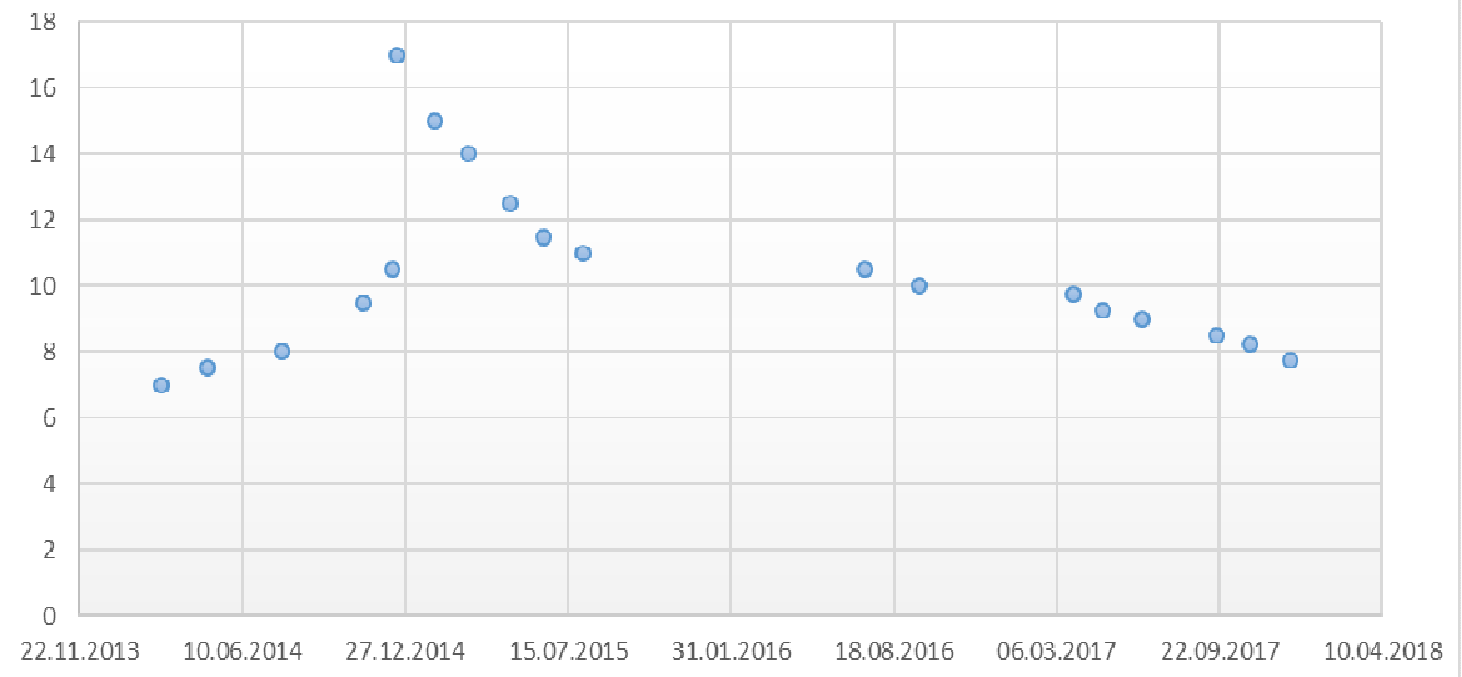

Fig. 2. Dynamics of the key interest rate for the period 2013-2017. (5)

The Bank of Russia justifies this rigid monetary policy by the need to curb inflation, which in future should contribute to the growth of investments (primarily external ones). Obviously, high inflation deprives the investor of motives (first of all, the external ones) to invest in Russian companies, since all of the future profits might be depreciated. Of course, such a remark can be applied to domestic investors. However, the situation is not so simple: firstly, such an investor not only has business in Russia, but also spends money inside the country, and so he/she depends on the domestic economy. Secondly, in the context of the Western sanctions policy, investing outside Russia is risky.

However, both the economic logic and the real life show the senselessness of the Central Bank policy, since it is obvious that no matter how low the inflation is, there will be no foreign investment. The impasse is obvious: a strict monetary policy does not provide an opportunity to form an internal investment, despite the records in the field of inflation targeting.

In fact, when we talk about domestic investment, we mean the availability of money in the country. It is well illustrated by such an indicator as the monetization coefficient (most often calculated as the ratio of the size of the monetary aggregate M2 to GDP) (Figure 3).

Undoubtedly, in recent years the indicator has been growing, but if you compare it with the indicators of the developed countries, then a gap is obvious, for which the normal value of this indicator is $70-90 \%$ and even more (Fig. 4).

In such a situation, Russian companies lack financing. Obviously, in such macroeconomic conditions, regional authorities have very few support measures for enterprises, since they themselves are in harsh conditions. And this is all in the conditions of low budget independence (for example, at 
the end of 2016 in Russia, out of 85 subjects only 13 were financially independent). (7)

Obviously, the regions are not able to influence the monetary and credit policy of the state, and in the context of the economic downturn and a poor interbudgetary policy, investment opportunities in the regions are severely restricted.
In this sense, the example of Tambov region is quite indicative. Tambov region lacks budget financing. In particular, in 2014 the deficit amounted to 2.367 billion rubles, in 2015 it was 2.053 billion rubles, in 2016 it was 2.78 billion rubles. (8) Besides the region had to meet social demands.

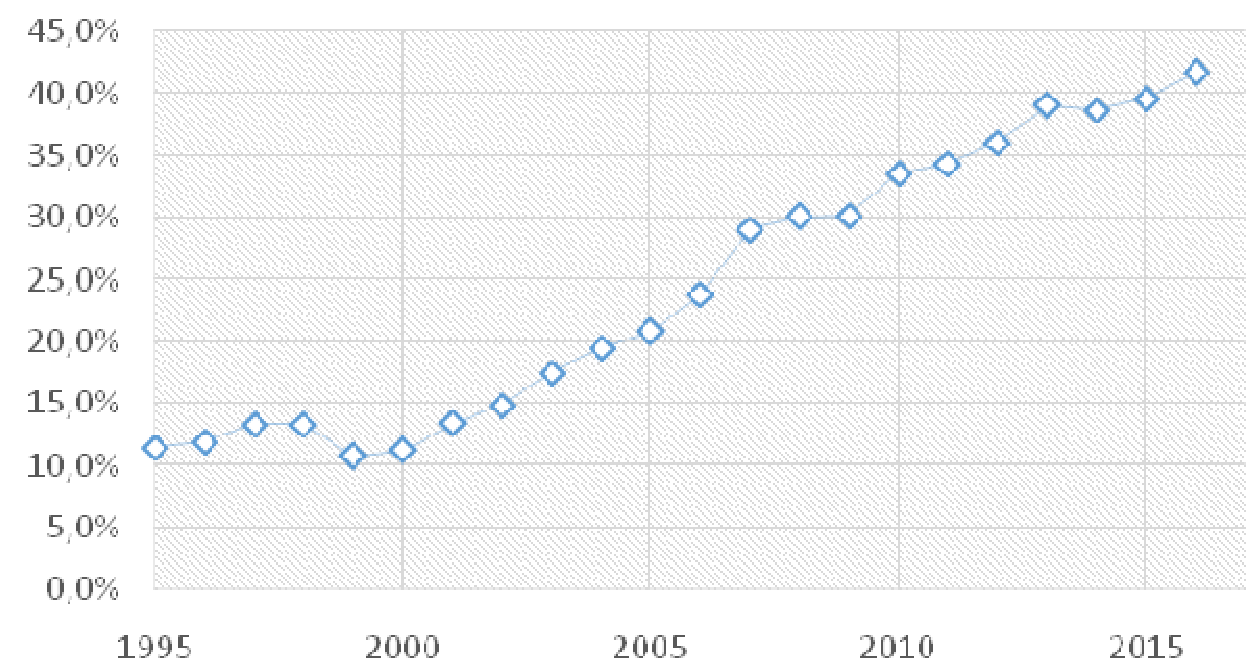

Fig.3.Dynamics of growth of the monetization coefficient of the Russian economy.(6)

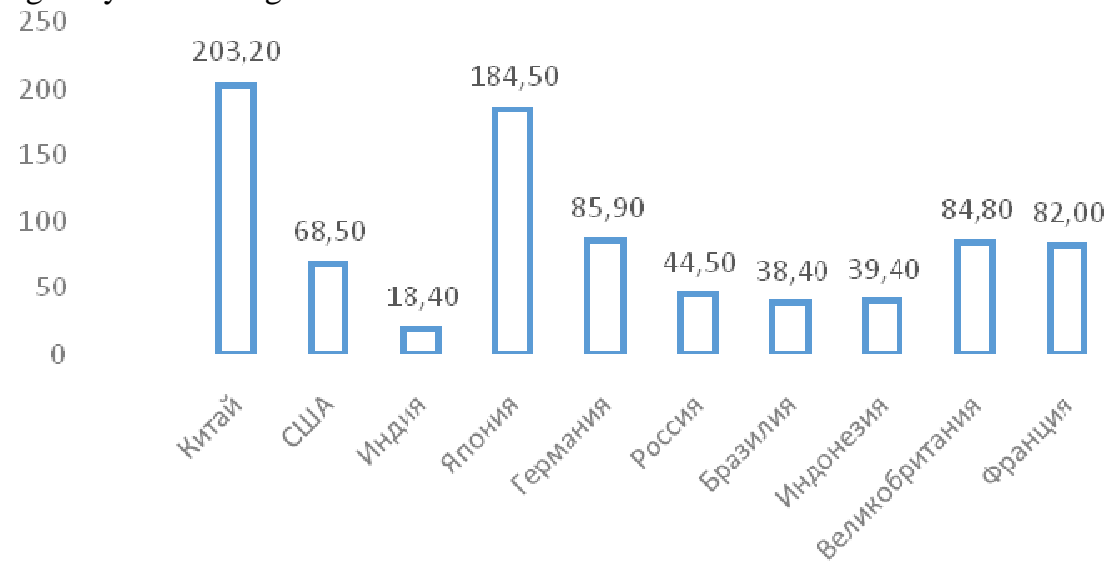

Fig. 4. Comparative evaluation of the monetization of the 10 largest economies of the world at the end of 2015 (6)

In such a situation, public-private partnership (hereinafter PPP) becomes the only mechanism for fulfilling economic and social tasks, as well as for providing investment support in the region. At the same time, we should not forget that any PPP project does not only create a new enterprise or fulfils some state task, but it also has a multiplicative effect:

- jobs are created;

- tax revenues from the new business are increasing (despite some tax breaks);
- the state receives additional revenues (for example, a concession fee).

Tambov authorities got this message. According to the Association called "The Center for PPP Development", Tambov region made a big breakthrough within the last 4 years (9). This is evidenced by the estimates of the National Center for Public-Private Partnerships (Figure 5)

In 2016, according to the level of PPP, Tambov region outperformed almost all of its neighbors in the Central Federal District (Figure 6). 


\begin{tabular}{|r|c|c|c|c|}
\hline Год & ИП & Место & Изменение ИП & $\begin{array}{c}\text { Изменение } \\
\text { места }\end{array}$ \\
\hline $\mathbf{2 0 1 3 - 2 0 1 4}$ & $40,7 \%$ & 29 & - & - \\
\hline $\mathbf{2 0 1 4 - 2 0 1 5}$ & $46,7 \%$ & 18 & $+6 \%$ & +11 \\
\hline $\mathbf{2 0 1 5 - 2 0 1 6}$ & $40,4 \%$ & 13 & $-6,3 \%$ & +5 \\
\hline $\mathbf{2 0 1 6 - 2 0 1 7}$ & $62,3 \%$ & 14 & $+21,9 \%$ & -1 \\
\hline
\end{tabular}

Fig. 5. The dynamics of the situation in Tambov region in the ranking of regions in terms of the level of PPP development. (10)

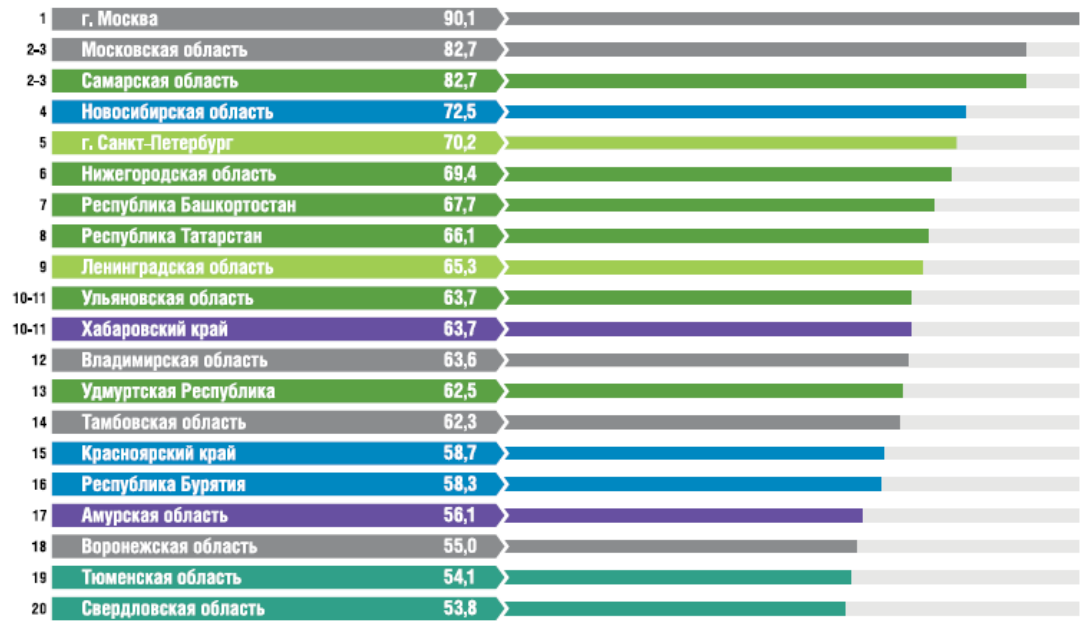

Fig. 6. The position of Tambov region in the ranking of regions according to the level of PPP development (10)

\section{Conclusion}

The comparative success of Tambov region (in relation to most other regions of the Central Federal District), noted in Table. 1, is not just a coincidence. This is mostly the result of the targeted efforts of the regional authorities. This is also evident in the conditions of low indicators of the region budget independence. In this sense, public-private partnership is nearly the only working mechanism for supporting the investment sphere in the region.

In 2016 the main form of PPP in Tambov region was a concession agreement: 133 agreements were signed (note that this is the main form used by regional authorities). (9) However, not everything is so perfect. For example, mainly, all PPP projects are implemented in the housing and communal services sector. At the same time, Tambov region has no experience in implementing PPP projects in the social sphere. In this sense, the urgent target of the regional authorities is to expand PPP projects to other areas, as well as to use PPP instruments more broadly (rather than concession agreements). At the same time, the expert community notes a wide range of problems hampering the development of PPPs, including:

- underdevelopment of the regional legal environment;

- absence or weak development of institutions responsible for the development of PPPs in the regions;

- low level of budget independence of regions;
- prevalence of politics over the economy (the influence of political factors on economic decisions);

- low transparency and corruption in the decision-making process of PPP projects;

- lack of clear strategic planning;

- low professionalism of officials in the field of PPP.

All this shows that public-private partnership is not only a great potential (because of the vital need for such a partnership for both business and regional authorities and because of the low starting positions), but it also implies a large range of unresolved problems. To solve these problems, we need not only special laws, but also the transformation of management thinking, as well as flexibility in making decisions about the implementation of certain PPP projects.

\section{References}

[1] All sanctions of the West against Russia, URL: http://tass.ru/mezhdunarodnaya-panorama/

[2] Bulletin on current trends in the Russian economy. Investments in fixed assets and sources of their financing (2016), Analytical Center under the Government of the Russian Federation, September, ULR: http://ac.gov.ru/files/publication/a/10337.pdf

[3] Dynamics of investments in fixed assets (in comparable prices) to the previous period, http://www.gks.ru/wps/wcm/connect/rosstat_main/rosstat/ru/statistics/en terprise/investment/nonfinancial/\#

[4] Nabiullina spoke about changing the models of the development of the Russian economy, ULR: http://www.rbc.ru/economics/14/11/2016/5829b9229a7947388373a8f3 
[5] The key rate established by the Bank of Russia, ULR: http://www.consultant.ru/document/cons_doc_LAW_12453/886577905 315979b26c9032d79cb911cc8fa7e69

[6] Sutyagin V. Yu., Zagumennov VR, Ya.Yu. Radyukova, E.A. Kolesnichenko (2017). The causes of the monetary nature of the current crisis of the Russian economy, Models, systems, networks in economics, technology, nature and society, №2 (22).

[7] Kanunnikov A. Donors are tired. What the heads of impoverished regions asked Moscow, FederalPress, URL: http://fedpress.ru/article/1726226

[8] Dynamics of the budget deficit of the constituent entities of the Russian Federation in 2014-2016 in the context of
"May decrees" President Expert-analytical report (2014), Center for Political Information, Moscow.

[9] Sutyagin V. Yu., Radyukova Y. Yu. (2017) State-private partnership: exotic or vital necessity, Public-private and municipal-private partnership in the regions of Russia: experience and practice. Materials of the all-Russian scientific-practical conference, Tambov.

[10] Public-Private Partnership in Russia 2016-2017: Current Status and Trends, Regions' Rating, Association PPP Development Center, $32 \mathrm{p}$. 